\title{
ECONOMICS OF HERBICIDE USE IN CEREAL CROPS - INFLUENCE OF SPRING RAINFALL
}

\author{
G.W. BOURDOT, D.J. SAVILLE and G.A. HURRELL \\ AgResearch, New Zealand Pastoral Agriculture Research Institute Ltd, P.O. Box 60, \\ Lincoln
}

\begin{abstract}
Relationships between spring rainfall and yield losses prevented by herbicides in wheat and barley in Canterbury were used in a simple bio-economic model to evaluate the effects of spring rainfall on the economics of herbicide application in these crops. The model assumed herbicide application has no flow-on economic consequences for succeeding crops, and predicted the probability of breaking even (or better) on prophylactic use of herbicide in wheat and barley over a range of September and October rainfall levels respectively. The analysis revealed that while such herbicide usage is economic in many crops in many seasons, there is potential for withholding herbicides, particularly in seasons with low spring rainfall.
\end{abstract}

Keywords: weed control, model, economics, yield losses, rainfall

\section{INTRODUCTION}

Herbicides are essential tools in intensive agriculture worldwide. However, increasing concern about possible environmental side effects, particularly ground and surface water pollution (Klaseus et al. 1988), the evolution of herbicide resistance in weed populations (LeBaron and Gressel 1982; Powles and Holtum 1994) and the general economic necessity to reduce the costs of inputs in agriculture, are resulting in increasing pressure on farmers to reduce herbicide use. This has led to attempts to eliminate cosmetic and prophylactic use of herbicides through the development of weed control advisory systems using economic thresholds (Niemann 1986; Aarts and de Visser 1985; Wahmhoff and Heitefuss 1988).

In an effort to determine the extent to which a threshold approach to weed control decision making may contribute to a rational reduction in the use of herbicides, Bourdot et al. (1996) collected data on prevented yield losses in 59 wheat and 45 barley crops. These data were used to refine a method developed earlier (Bourdot and Saville 1988) for estimating the proportion of fields of a particular crop in a particular region for which herbicide use is likely to be economic. The study concluded that, as a long term average, the use of commonly applied herbicides is likely to be economic in $75 \%$ of wheat and barley crops in Canterbury. However, the weed-induced yield losses prevented by herbicide treatment in wheat and barley were positively correlated with September and October rainfall respectively in the year of sowing. This correlation suggests that weeds are generally more competitive and cause greater losses in grain yield when spring soil moisture levels are high.

In the current paper we explore this correlation and its consequences for the economics of herbicide use in wheat and barley crops in Canterbury.

\section{MATERIALS AND METHODS}

In the study by Bourdot et al. (1996), prevented yield losses were determined in 59 fields of wheat over five consecutive years (1989, 90, 91, 92 and 93) and in 45 fields of barley over three years (1991, 92 and 93). From that study, the regression lines relating the annual average prevented yield loss $\left(\overline{\mathrm{L}}_{\mathrm{P}}\right)$ to rainfall, and their $95 \%$ confidence limits, are: 


$$
\begin{aligned}
& \text { Wheat: } \bar{L}_{P}=\left(-0.107+0.0124 \times R_{S}\right) \pm 0.614 \times \sqrt{\frac{1}{5}+\frac{\left(R_{S}-46.1\right)^{2}}{3498}} \\
& \text { Barley: } \bar{L}_{P}=\left(-0.186+0.0114 \times R_{O}\right) \pm 1.219 \times \sqrt{\frac{1}{3}+\frac{\left(R_{O}-48.1\right)^{2}}{1974}}
\end{aligned}
$$

where $R_{S}$ and $R_{O}$ are the rainfall totals $(\mathrm{mm})$ for September and October, respectively, taken as the average values for the five meteorological stations covering the study area in Canterbury (Winchmore, Ashburton, Darfield, Christchurch Airport and Lincoln).

Also from that study, the probability that a farmer will break even (or better) on weed control in a random crop is given by:

$$
\begin{aligned}
& \text { Wheat: } \operatorname{Pr} o b=\Phi\left[\frac{\bar{L}_{P}-\frac{C}{P}}{s}\right]=\Phi\left[\frac{\bar{L}_{P}-\frac{20}{237}}{0.366}\right] \\
& \text { Barley: } \operatorname{Pr} o b=\Phi\left[\frac{\bar{L}_{P}-\frac{C}{P}}{s}\right]=\Phi\left[\frac{\bar{L}_{P}-\frac{12}{201}}{0.457}\right]
\end{aligned}
$$

where $\Phi$ is the standard cumulative normal distribution function, $\bar{L}_{P}$ is the mean yield loss for a particular year, $s$ is the standard deviation of yield losses pooled over years for which data has been collected, $C$ is the net cost of herbicide treatment (\$/ha) and $P$ is the net value of the harvested grain (\$/tonne).

For our present analysis, 1995 values for $C$ and $P$ were estimated to be $C=\$ 20 /$ ha and $P=$ $\$ 237 /$ tonne for wheat, and $C=\$ 12 /$ ha and $P=\$ 201 /$ tonne for barley (Bourdot et al. 1996). These estimates were obtained using the method described in Bourdot and Saville (1990) where the net treatment cost $(C)$ was the sum of the herbicide cost plus the cost of its application, minus estimated annual cost savings associated with avoidance of pre-harvest crop desiccation, post-harvest grain drying and cleaning. The net value of the grain $(P)$ was calculated as the gross price received for the harvested grain minus the costs of harvesting and transporting the grain and minus the estimated annual cost of preharvest crop desiccation and post-harvest grain drying when the latter two are needed in the weed-free crop. In addition, pooled $s$ values were 0.366 and 0.457 for wheat and barley, respectively (Bourdot et al. 1996).

To express this probability as a function of spring rainfall, the expressions for $\bar{L}_{P}$ given in equations (1a) and (1b) were substituted into equations (2a) and (2b) respectively. The probability of breaking even (or better) was then calculated for the spring rainfalls which occurred in each of the years 1947 to 1994.

\section{RESULTS AND DISCUSSION}

The probabilities of breaking even in random wheat and barley crops are given as functions of spring rainfall in Figures 1 (a) and 1 (b) respectively. For both cereal crops, this probability ranged from 35 $40 \%$ for a monthly rainfall of $6 \mathrm{~mm}$ (the minimum for the period 1947 to 1994), up to $100 \%$ for a monthly rainfall of $122 \mathrm{~mm}$ (the corresponding maximum). 

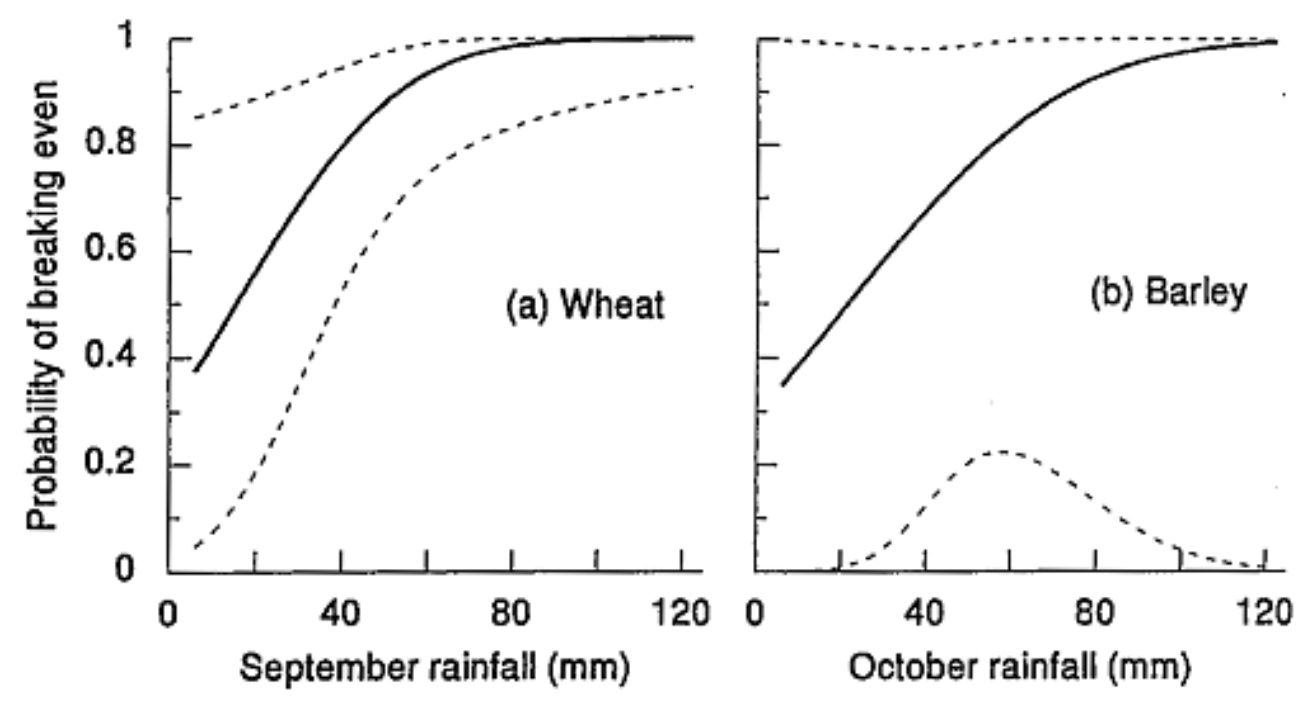

FIGURE 1: The probability of breaking even (or better) from weed control using herbicide in a random crop of (a) wheat and (b) barley as a function of (a) September and (b) October total monthly rainfall $(\mathrm{mm})$. The solid line is the best estimate and the broken lines are the lower and upper $95 \%$ confidence limits.
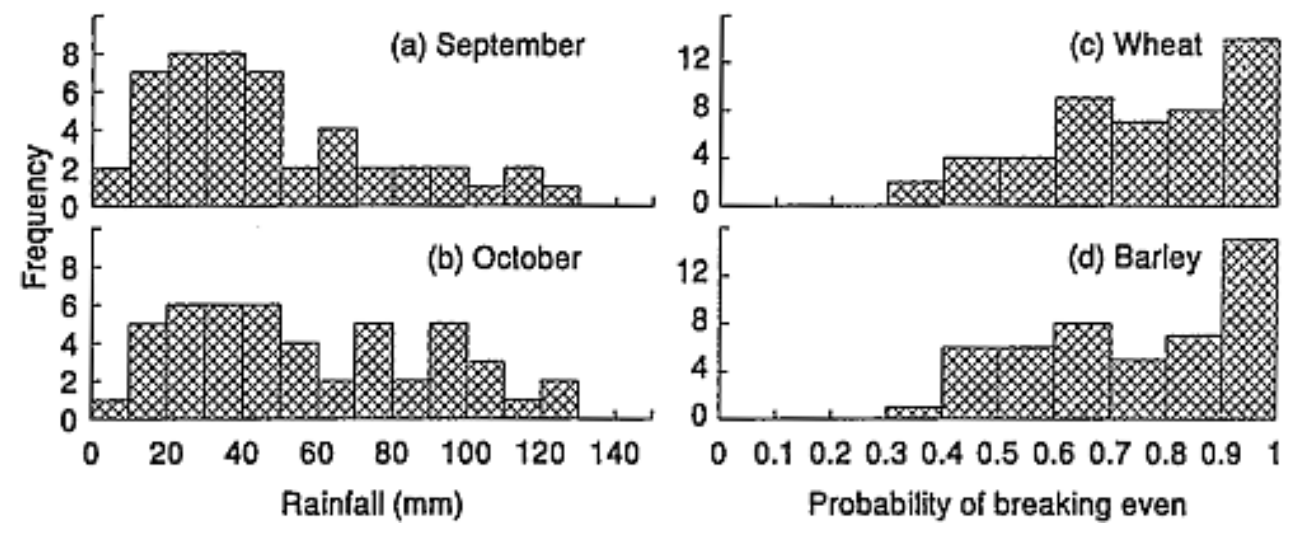

FIGURE 2: Histograms of (a) September and (b) October total monthly rainfalls (mm) for the years 1947 to 1994 inclusive, and the best estimates of the probabilities of breaking even (or better) from weed control using herbicide in a random crop of (c) wheat and (d) barley for the years 1947 to 1994 inclusive.

Figures 2(a) and 2(b) summarise the September and October monthly rainfalls for the 48 years (1947 to 1994), and Figures 2(c) and 2(d) summarise the corresponding probabilities of breaking even. In the case of wheat, the predicted probability of breaking even was less than a 50\% chance in 6 out of the 48 years (13\% of years), and greater than an $80 \%$ chance in 22 out of the 48 years ( $46 \%$ of years). In the case of barley, the probability of breaking even was less than a $50 \%$ chance in 7 out of the 48 years $(15 \%$ of years), and greater than an $80 \%$ chance in 22 out of the 48 years (46\% of years).

These results suggest that while the common practice of prophylactic use of herbicides in wheat and barley in Canterbury is often economic, there is potential for withholding herbicides, particularly in seasons with low spring rainfall. For example, when September and October rainfalls are as low as $6 \mathrm{~mm}$, as they were in 1980 and 1961, the model predicts that the farmer will break even (or better) in only $35 \%$ 
and $38 \%$ of wheat and barley crops respectively. If these "uneconomic-to-treat" crops could be identified in advance of the time when herbicide treatments need to be applied, then the treatment could be withheld and crop profitability increased. Models to forecast crop yield loss based on the relative leaf area of weeds may be suitable for this purpose (Kropff and van Laar 1993), and are the subject of a research programme in Canterbury. Such forecasts could provide the basis of an economic threshold model for weed control decisions in individual fields. However, the current probabilistic model also has some decision support application. In Canterbury, wheat and barley crops are usually treated with herbicide in October and November respectively. This means that it would be possible for the decision to apply/withhold herbicide treatment to be made on the basis of September rainfall for wheat and October rainfall for barley. Our conclusions rest on the validity of the assumptions we have made in our model (see Bourdot et al. (1996), for further discussion). A most important assumption is that there are no carry-over economic benefits (or costs) to future years from controlling (or not controlling) weeds in the current crop. We have made this simplifying assumption because the consequences of weed control imposed in the current crop, for future weed population growth, cannot be predicted from current understanding (Mortimer 1983).

\section{ACKNOWLEDGEMENTS}

We thank the Foundation for Research, Science and Technology for funding this project, Christine Galbraith for help with the technical aspects of the project and the growers of the wheat and barley crops who kindly allowed the experimental plots in their fields. We also thank Peter Jamieson, Crop \& Food Research, for helpful discussion concerning the rainfall data.

\section{REFERENCES}

Aarts, H.F.M. and de Visser C.L.M., 1985. A management information system for weed control in winter wheat. Proc. 1985 British Crop Prot. Conf. - Weeds, 7A- 2: 679-686.

Bourdot, G.W. and Saville D.J., 1988. The economics of herbicide use in cereal crops in New Zealand. N.Z. J. Exp. Agric. 16: 201-207.

Bourdot, G.W. and Saville D.J., 1990. Calculating the economics of weed control. Proc. 43rd N.Z. Weed and Pest Control Conf.: 258-61.

Bourdot, G.W., Saville, D.J., Hurrell, G.A. and Daly, M.J., 1996. Modelling the economics of herbicide treatment in wheat and barley using data on prevented grain yield losses. Weed Res. (accepted).

Klaseus, T.G., Buzicky, G.C. and Schneider, E.G., 198S.Pesticides and Groundwater:Surveys of selected Minnesota wells. Prepared for the Legislative Commission on Minnesota Resources by the Minnesota Department of Agriculture and Health, St Paul, Minn.

Kropff M.J. and Van Larr H.H., 1993. Modelling crop-weed interactions. CAB International in association with the International Rice Research Institute, 274pp.

LeBaron, H.M. and Gressel J., 1982. Herbicide Resistance in Plants. John Wiley and Sons, New York.

Mortimer, A.M., 1983. On weed demography. Pp. 3-40. In: Recent Advances in Weed Research, W.W. Fletcher (Ed). CAB, England.

Niemann, P., 1986. Mehrjahrige Anwendung des Schadensschwellenprinzips bei der Unkrautbekampfung auf einem landwirtschaftlichen Betrieb. Proc. European Weed Research Society Symp. 1986, Economic Weed Control, Stuggart-Hohenheim, Germany, pp. 385-92.

Powles, S.B. and Holtum, J. A.M., 1994. Herbicide Resistance in Plants: Biochemistry and Biology. Lewis Publishers, Boca Raton, FL.

Wahmhoff, W. and Heitefuss, R., 1988. Studies on the use of economic injury thresholds for weeds in winterbarley. Pp 59-91 In: PlantResearch and Development; A Biannual Collection of Recent German Contributions. Institut fur Wissenschaftliche Zusammenarbeit, Tubingen, Germany, Vol 27. 